\title{
STRATEGI DALAM MENGEMBANGKAN POTENSI WISATA SITU LEMBANG DANO DI DESA CIPADA
}

\author{
Tita Juwita
}

Prodi Magister Pariwisata Berkelanjutan SPs Universitas Padjadjaran Bandung Email: tita18005@mail.unpad.ac.id

\section{Reiza D. Dienaputra}

Prodi Magister Pariwisata Berkelanjutan SPs Universitas Padjadjaran Bandung Email: reizaputra@yahoo.com

\section{Awaludin Nugraha}

Prodi Magister Pariwisata Berkelanjutan SPs Universitas Padjadjaran Bandung Email: awaludin.nugraha@unpad.ac.id

\section{Evi Novianti}

Prodi Magister Pariwisata Berkelanjutan SPs Universitas Padjadjaran Bandung Email: novianti.vi@gmail.com

\section{Rusdin Tahir}

Prodi Magister Pariwisata Berkelanjutan SPs Universitas Padjadjaran Bandung Email: rusdintahir@gmail.com

\begin{abstract}
This study aims to find out how the development strategy of Lembang Dano situ in Village of Cipada, and to get the right strategy for the development of Lembang Dano tourist attractions. The data has taken of primary data and secondary data, where primary data is obtained from questionnaires and interviews to predetermined sources and secondary data obtained from agencies and agencies related to this study. The analytical tool used the SWOT analysis method the results of the research show that the development strategy needs to first determine the factors that are strengths and weaknesses (internal environment) ourism potential in Lembang Dano Cipada Village, then combines with the opportunities and threats from outside (external environment).
\end{abstract}

Keywords: development strategy, Tourism, Situ lembang Dano, Village of Cipada 


\section{Pendahuluan}

Dalam upaya mendukung pembangunan fasilitas pariwisata di destinasi wisata, Kementerian Pariwisata menetapkan pedoman pengembangan daya tarik wisata dan peningkatan amenitas pariwisata yang secara lebih rinci menggambarkan mengenai norma pembangunan, standar pembangunan, prosedur pembangunan, kriteria pembangunan, dan standar biaya yang menjadi landasan dalam pelaksanaan kegiatan DAK Fisik Bidang Pariwisata (Permenpar no 3 Tahun 2018).

Pembangunan pariwisata sangat berperan penting dalam meningkatkan devisa negara. Selain itu pariwisata mempunyai peran dalam meningkatkan jati diri bangsa dan mendorong kesadaran masyarakat dan bangga pada kekayaan dan keindahan juga keunikah alam, laut, museum dan berbagai macam tradisi dan kebudayaan sebagai alat yang efektif untuk melestraikannya (Sumantri Diaz : 29).

Kabupaten Bandung Barat adalah Kabupaten yang sangat mempunyai potensi pariwisata nya, Bandung Barat memiliki potensi sumberdaya pariwisata yang beranekaragam, mulai dari atraksi wisata alam, atraksi wisata budaya dan atraksi wisata buatan manusia, yang didukung dengan kondisi lingkungan alam, lingkungan sosial budaya.

Luas wilayah Kabupaten Bandung Barat adalah 13.027.738 km2 kecamatan yang memiliki luas yang paling besar adalah kecamatan Gunung Halu yaitu 160,7 km2 sedangkan luas kecamatan yang paling kecil adalah kecamatan Ngamprah yaitu 36 km2.Luas wilayah Desa Cipada Kecamatan Cikalong Wetan 1.477.300 ha, Jumlah penduduk 1588 Jiwa. 


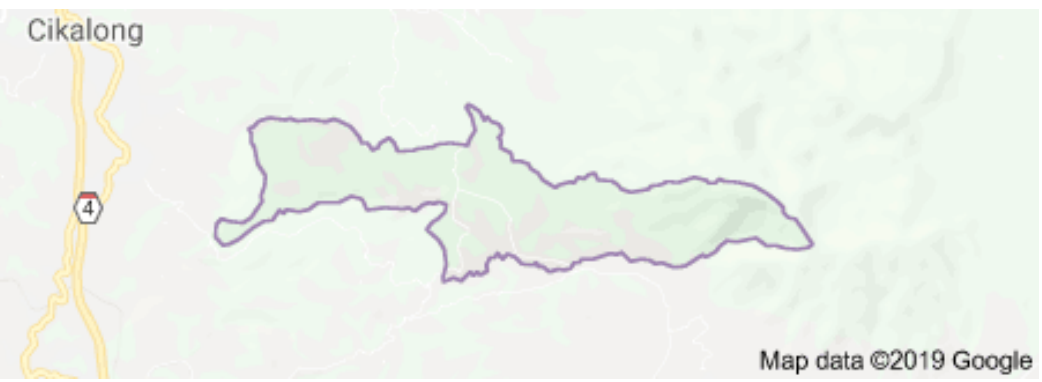

Gambar 1. Peta Desa Cipada Kecamatan Cikalong Wetan

Situ Lembang Dano adalah sebuah danau alam yang terletak di Desa Cipada, Kecamatan Cikalong Wetan, Kabupaten Bandung Barat (KBB). Danau alam ini belum dikelola secara profesional oleh pemerintah KBB dan kini kondisinya sangat memprihatinkan karena sudah terjadi pedangkalan. Jika tidak diperhatikan oleh pemerintah, bukan mustahil suatu saat danau yang berada di kaki Gunung Burangrang ini akan hilang. Selain itu situ lembang dano kurang mendapatkan perhatian masyarakat sehingga wilayah situ tersebut semakin berkurang karena tidak di kelola dengan baik. Sehingga perlu keterlibatan pemerintah juga masyarakat untuk mengembangkan situ lembang dano menjadi tempat wisata yang menarik wisatawan untuk datang sehingga dapat meningkatkan penghasilan desa Cipada.

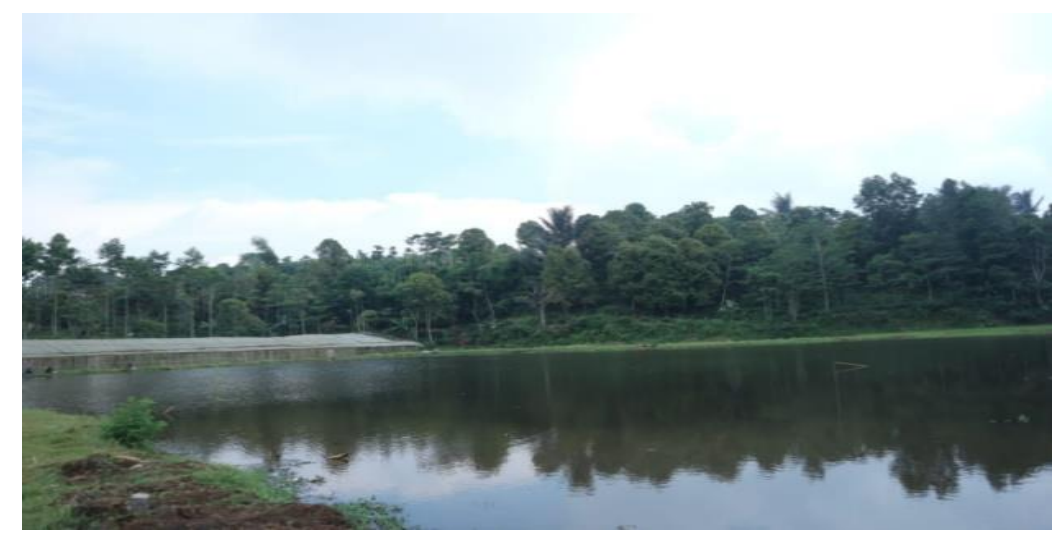

Gambar 2. Situ Lembang Dano Desa Cipada 
Sumber daya alam Desa Cipada lokal yang ada, orang-orang dan organisasi lokal, mendukung ada nya tempat wisata alam dan pertanian, dan membantu menciptakan identitas dan memberikan pilihan yang berbeda untuk wisatawan. Sebagai objek wisata itu dapat mempengaruhi daerah dan masyarakat setempat terutama dalam hal ekonomi, yang mempengaruhi peningkatan infrastruktur dan pembangunan yang penting bagi kualitas hidup. Pemerintah daerah adalah kekuatan utama untuk mempromosikan dan mendukung penciptaan produk dan layanan lokal dengan meningkatkan dan mengembangkan produk dan sumber daya yang ada untuk meningkatkan pangsa pasar dan menawarkan lebih banyak pilihan bagi wisatawan, dan mengurangi dampak negatif terhadap lingkungan dengan menggunakan konsep berkelanjutan sehingga dapat mencapai manfaat tertinggi.

Kearifan lokal harus difokuskan pada pembuatan produk-produk unik untuk mendukung penduduk sebagai konsep berbasis masyarakat, dan wisata jalan-jalan dengan perahu akan disediakan oleh masyarakat setempat, termasuk pertunjukan dan pertunjukan yang dilakukan oleh masyarakat Desa Cipada. Saat ini jumlah wisatawan terus meningkat dan pasar terus dengan cara pembangunan berkelanjutan dan peningkatan faktor dan operasi terkait. Ini bisa menjadi model untuk pasar terapung dengan cara yang paling positif dan dapat dengan jelas dinyatakan bahwa Desa Cipada adalah desa agro industri yang dapat menunjukkan pengelolaan pariwisata berkelanjutan dan pariwisata berbasis masyarakat, yang secara langsung dipengaruhi oleh ekonomi berbasis masyarakat yang konstan dan masyarakat dengan baik.

$414 \quad$ JUMPA Volume 7, Nomor 2, Januari 2021 


\section{Metode}

Penelitian ini dilakukan pada bulan Maret 2019 di Situ Lembang Dano Desa Cipada Kecamatan cikalong Wetan Kabupaten Bandung Barat. Mengidentifikasi Faktor Internal dan Eksternal (Komponen SWOT) yang diperoleh dengan menggunakan metode obervasi, dilakukan dengan cara mengamati secara langsung aktivitas di kawasan atau di sekitar kawasan yang berhubungan dengan penelitian ini serta metode wawancara dan penyebaran kuisioner yang berisikan pertanyaan pertanyaan kunci untuk mengetahui kondisi sosial masyarakat tentang Situ Lembang Dano dan aktivitasnya. Perumusan kedua faktor tersebut dapat di gambarkan dalam benttuk Matrik SWOT Dan strategi yang diperoleh adalah ST, WO dan WT.

Tabel 1. Matrik SWOT dan TOWS

\begin{tabular}{|c|c|c|}
\hline Faktor - Faktor Faktor Internal & $\begin{array}{l}\text { Kekuatan } \\
\text { (Strenghts) }\end{array}$ & $\begin{array}{l}\text { Kelemahan } \\
\text { (Weaknesses) }\end{array}$ \\
\hline $\begin{array}{l}\text { Peluang } \\
\text { (opportunities) }\end{array}$ & $\begin{array}{l}\text { Strategi SO } \\
\text { Ciptakan strategi yang } \\
\text { menggunakan kekuatan } \\
\text { dengan memamfaatkan } \\
\text { peluang }\end{array}$ & $\begin{array}{l}\text { Strategi WO } \\
\text { Ciptakan strategi yang } \\
\text { meminimalkan kelemahan } \\
\text { dengan memamfaatkan } \\
\text { peluang }\end{array}$ \\
\hline Ancaman (Threats) & $\begin{array}{l}\text { Strategi ST } \\
\text { Ciptakan Strategi yang } \\
\text { menggunakan kekuatan } \\
\text { untuk mengatasi ancaman }\end{array}$ & $\begin{array}{l}\text { Strategi WT } \\
\text { Ciptakan strategi yang } \\
\text { meminimalkan kelemahan } \\
\text { dan menghindari ancaman }\end{array}$ \\
\hline
\end{tabular}




\section{Analisis Deskriptif Kualitatif}

Menganalisis kondisi tempat wisata dari masyarakat tetang persepsi, dan aktivitas dengan menggunakan metode wawancara dan penyebaran kuisioner, kemudian data di analisis sehingga memperoleh suatu arahan pengelolaan dalam mengembangkan kawasan wisata.

\section{Hasil Penelitian dan Pembahasan}

Sebelum melakukan strategi pengembangan, perlu terlebih dahulu menentukan faktor-faktor yang menjadi kekuatan dan kelemahan (lingkungan internal) potensi wisata situ lembang dano desa cipada, kemudian memadukan dengan faktor-faktor peluang dan ancaman dari luar (lingkungan eksternal).

A. Faktor-faktor kekuatan (Strength):

1) Terdapat lahan petanian yang luas.

2) Terdapat kesenian tradisional Berupa Pencak Silat

3) Terdapat organisasi karang taruna

4) Terdapat Pembuatan Kopi Tradisional Khas Cipada

B. Faktor-faktor Kelemahan (Weaknesses)

1) Kurangnya aksesibilitas menuju Desa Cipada, yang disebabkan oleh jarak yang jauh dari sentral pariwisata Kabupaten Bandung Barat, kondisi jalan yang berliku-liku serta adanya jalan alternatif yang rusak.

2) Kurang tersedianya prasarana dan sarana penunjang pariwisata, yang mana di Kecamatan Cikalong Wetan tidak terdapat Fasilitas Akomodasi. 
3) Kurang tersedianya sumber daya manusia yang memiliki pengetahuan dan keterampilan di bidang pariwisata.

4) Kurangnya promosi dan kerjasama dengan Pemerintah yang diakibatkan oleh keterbatasan sumber daya manusia dan dana.

C. Faktor-faktor Peluang (Opportunities)

1) Mempunyai Potensi Wisata di lingkungan situ Lembang Dano.

2) Kecenderungan wisatawan lokal dan wisatawan asing untuk menikmati destinasi pariwisata yang mempunyai konsep alam.

3) Dengan kemajuan teknologi informasi dan komunikasi maka dapat mempromosikan daerah tujuan wisata ke berbagai wilayah dan dengan kemajuan alat transportasi, jarak yang jauh tidak lagi menjadi kendala utama dalam melakukan perjalanan wisata.

4) Citra pariwisata Kabupaten Bandung Barat yang baik. Keunikan dan keragaman alam, termasuk keramahtamahan orang Bandung yang sudah terkenal di Indonesia.

D. Faktor-faktor Ancaman (Threats)

1) Kondisi Lingkungan yang berada di kawasan Patahan Lembang yang rawan Gempa

2) Krisis ekonomi global yang mempengaruhi hampir seluruh penduduk dunia dapat menyebabkan menurunnya pendapatan penduduk dunia dan mengurangi motivasi untuk melakukan perjalanan.

3) Situasi politik dan ekonomi nasional yang tidak stabil. Masalah-masalah politik dan korupsi yang tidak pernah tuntas sewaktu-waktu dapat 
mengganggu keamanan dan ekonomi nasional serta mempengaruhi pariwisata.

4) Persaingan yang ketat antara daerah tujuan wisata baik di dalam maupun luar negeri.

Strategi dan Program Pengembangan

Berdasarkan analisis matriks SWOT, strategi pengembangan situ lembang dano adalah sebagai berikut.

A. Strategi Strength Opportunites (SO), merupakan strategi yang menggunakan kekuatan untuk memanfaatkan peluang, menghasilkan strategi pengembangan dan diversifikasi produk serta mempertahankan keaslian daya tarik wisata tersebut. Program-program pengembangan yang perlu dilakukan adalah sebagai berikut.

\section{Wisata Trekking}

Menyusuri keindahan alam pertanian, perkebunan dan keanekaragaman mata pencaharian masyarakat seperti bertani, dengan berjalan kaki merupakan pengalaman yang menarik bagi wisatawan. Kehidupan para petani yang masih tradisional seperti, menanam sayuran, memberi pupuk sayuran, memetik teh dan memetik kopi dan sebagainya akan menjadi sumber informasi yang sangat menarik bagi wisatawan karena hal tersebut merupakan sesuatu yang langka bagi mereka.

2. Wisata Pemancingan

Pengembangan wisata pemancingan di Desa Cipada didasari atas keberadaan situ lembang dano sebagai tempat wisata yang mempunyai beragam ikan untuk di 
pancing. Wisatawan yang memiliki hobby memancing, berperahu dapat menghabiskan waktunya di situ lembang dano.

3. Wisata Kuliner

Situ Lembang Dano yang terkenal dengan produksi ikan perlu dikembangkan wisata kuliner seperti Desa Cipada. Hal tersebut sangat cocok di bangun tempat makan khusus ikan-ikan yang berada di kawasan situ lembang dano. Makanan yang disuguhkan berupa masakan dari ikan seperti ikan goreng, ikan bakar, sate ikan, pepes ikan, sup ikan dengan beraneka bumbu seperti sambal bawang mentah, sambal sere, sambal terasi, sambal tomat, sambal kecap dan lain sebagainya, sekaligus di suguh kan Kopi dan Teh Khas desa Cipada.

4. Wisata Outbound

Lokasi sekitar Situ Lembang Dano yang luas cocok untu di jadikan tempat outbound karena lingkungan sekitar yang sangat indah dan berada di kaki gunung burangrang yang cocok untuk di jadikan tempat wisata outbound.

5. Wisata Kesenian Pencak Silat

Desa Cipada memiliki tokoh seniman pencak silat yang sudah terkenal dan berpengalaman dalam mengajar pencak silat di daerah sekitar Desa Cipada

6. Wisata Agro.

Desa Cipada, merupakan wilayah pertanian dan perkebunan sangat luas yang dapat dimanfaatkan sebagai daya tarik wisata agro. Dengan harga tertentu wisatawan dapat dilibatkan dalam kegiatan-kegiatan pertanian seperti memetik menanam sayuran, memetik daun teh, belajar cara pembibitan, penananam dan pemeliharaan tanaman pada petani lokal. 


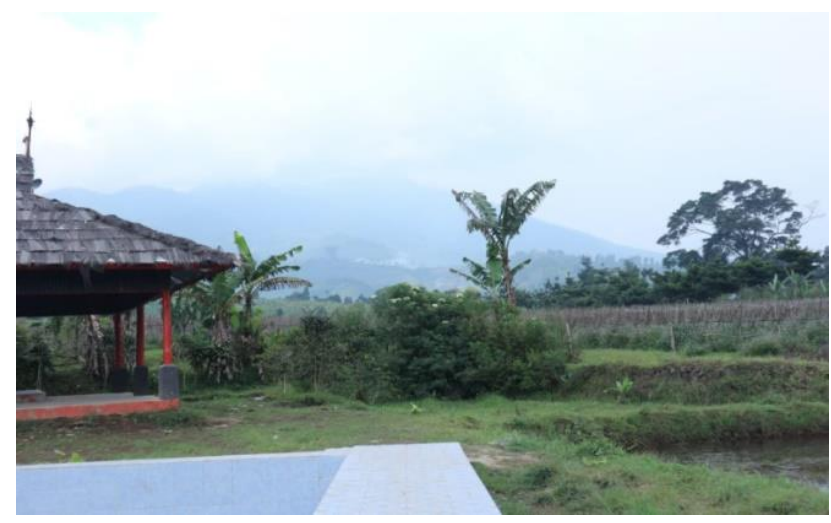

Gambar. 3 Daerah Perkebunan Lingkungan Situ Lembang Dano

B. Strategi Strength Threats (ST), merupakan strategi yang menggunakan kekuatan untuk mengatasi ancaman, menghasilkan strategi peningkatan keamanan dan kenyamanan daya tarik wisata dengan program seperti menjaga dan meningkatkan keamanan situ lembang Dano dan lingkungan Desa Cipada, Kecamatan Cikalong Wetan. Peningkatan keamanan dilakukan dengan menerapakan prosedur mitigasi di dalam tempat wisata dan area sekitar Desa Cipada.

C. Strategi Weaknesses Opportunities (WO), merupakan strategi yang meminimalkan kelemahan untuk memanfaatkan peluang, menghasilkan strategi pengembangan prasarana/sarana pokok dan penunjang pariwisata dan strategi promosi. Program-progam yang dilakukan adalah sebagai berikut.

1) Menyediakan dan memelihara fasilitas kamar mandi/toilet.

2) Menyediakan fasilitas parkir.

3) Memperbaiki jalan yang rusak

4) Menyediakan fasilitas akomodasi dengan memanfaatkan rumah-rumah penduduk. 
5) Menyediakan fasilitas rumah makan yang menyajikan makanan khas tradisional.

6) Membangun pasar kuliner tradisional yang lebih baik seperti pengemasan kopi dan teh khas Desa cipada

7) Mengadakan pertunjukan kesenian Pencak Silat di daerah tersebut.

8) Mendirikan Tourist Information Services (TIS) dengan bekerjasama dengan biro perjalanan wisata atau pramuwisata yang ada di Bandung sehingga mempermudah pemasaran terhadap daya tarik wisata lainnya.

D. Strategi Weaknnesses Threats (WT), merupakan strategi untuk meminimalkan kelemahan dan menghindari ancaman yang menghasilkan strategi pengembangan sumber daya manusia pariwisata melalui program-program sebagai berikut.

1. Membentuk lembaga pengelola pariwisata sehingga dapat mempermudah dalam melakukan perencanaan, pengelolaan dan kontrol terhadap kepariwisataan di Desa Cipada Kec Cikalong Wetan.

2. Meningkatkan kualitas sumber daya manusia (SDM) pariwisata. Hal ini dapat dilakukan melalui jalur pendidikan formal dan informal. Jalur formal dilakukan melalui pendidikan pada lembaga-lembaga pendidikan kepariwisataan mulai dari sekolah kejuruan sampai tingkat magister, sedangkan jalur informal dapat dilakukan melalui pelatihan-pelatihan pada industri pariwisata baik di hotel-hotel maupun di restoran.

3. Mengadakan penyuluhan sadar wisata. Dikarenakan sebagian besar masyarakat bekerja sebagai petani, buruh tani dan buruh pabrik yang kurang 
memahami arti pariwisata maka dari itu perlu disadarkan akan pentingnya pariwisata bagi mereka.

Analisis Strategi Pengembangan SWOT

Analisis strategi pengembangan dengan menggunakan analisis SWOT Identifikasi Faktor Internal dan eksternal yang dirumuskan dalam upaya menganalisis stretegi dalam mengembangkan Situ lembang Dano di Desa Cipada dapat di lihat sebagai berikut:

Analisis Faktor Internal

\begin{tabular}{|l|l|}
\hline $\begin{array}{l}\text { Kekuatan } \\
\text { (Strenghts) }\end{array}$ & Terdapat lahan petanian yang luas. \\
\hline & Terdapat kesenian tradisional Berupa Pencak Silat \\
\hline & Terdapat organisasi karang taruna \\
\hline & Terdapat Pembuatan Kopi Tradisional Khas Cipada \\
\hline
\end{tabular}

\begin{tabular}{|l|l|}
\hline $\begin{array}{l}\text { Kelemahan } \\
\text { (Weaknesses) }\end{array}$ & Kurangnya aksesibilitas menuju Desa Cipada \\
\hline & Kurang tersedianya prasarana dan sarana penunjang pariwisata \\
\hline & $\begin{array}{l}\text { Kurang tersedianya sumber daya manusia yang memiliki } \\
\text { pengetahuan dan keterampilan di bidang pariwisata }\end{array}$ \\
\hline & $\begin{array}{l}\text { Kurangnya promosi dan kerjasama dengan Pemerintah yang } \\
\text { diakibatkan oleh keterbatasan sumber daya manusia dan dana }\end{array}$ \\
\hline
\end{tabular}




\section{Analisis Eksternal}

\begin{tabular}{|l|l|}
\hline $\begin{array}{l}\text { Peluang } \\
\text { (Opportunities) }\end{array}$ & Wisata Trekking \\
\hline & Wisata Pemancingan \\
\hline & Wisata Kuliner \\
\hline & Wisata Outbound \\
\hline & Wisata Kesenian \\
\hline & Wisata Agro \\
\hline
\end{tabular}

\begin{tabular}{|l|l|}
\hline $\begin{array}{l}\text { Ancaman } \\
\text { (Threats) }\end{array}$ & $\begin{array}{l}\text { Kondisi Lingkungan yang berada di kawasan Patahan } \\
\text { Lembang yang rawan Gempa }\end{array}$ \\
\hline & Krisis ekonomi global \\
\hline & Situasi politik dan ekonomi nasional yang tidak stabil \\
\hline & Kurangnya promosi dan kerjasama dengan Pemerintah \\
\hline
\end{tabular}

Tabel 2. Matriks SWOT dan TOWS Strategi dalam Mengembangkan Situ Lembang Dano

\begin{tabular}{|c|c|c|}
\hline $\begin{array}{l}\text { Internal } \\
\text { Eksternal }\end{array}$ & $\begin{array}{l}\text { Kekuatan }(S) \\
\text { - } \begin{array}{l}\text { Terdapat lahan petanian } \\
\text { yang luas. }\end{array} \\
\text { - Terdapat kesenian } \\
\text { tradisional Berupa } \\
\text { Pencak Silat } \\
\text { - Terdapat organisasi } \\
\text { karang taruna } \\
\text { - Terdapat Pembuatan } \\
\text { Kopi Tradisional Khas } \\
\text { Cipada }\end{array}$ & $\begin{array}{l}\text { Kelemahan }(\mathrm{W}) \\
\text { - Kurangnya aksesibilitas } \\
\text { menuju Desa Cipada } \\
\text { - Kurang tersedianya } \\
\text { prasarana dan sarana } \\
\text { penunjang pariwisata } \\
\text { - Kurang tersedianya sumber } \\
\text { daya manusia yang } \\
\text { memiliki pengetahuan dan } \\
\text { keterampilan di bidang } \\
\text { pariwisata. }\end{array}$ \\
\hline
\end{tabular}




\begin{tabular}{|c|c|c|}
\hline & & $\begin{array}{lr}\text { - } \begin{array}{lr}\text { Kurangnya } \\
\text { kerjasama }\end{array} & \text { promosi dan } \\
\text { Pemerintah } & \text { dengan }\end{array}$ \\
\hline Peluang $(\mathrm{O})$ & $\mathrm{S}+\mathrm{O}$ & $\mathrm{W}+\mathrm{O}$ \\
\hline $\begin{array}{l}\text { - Wisata Trekkin } \\
\text { - Wisata Pemancingan } \\
\text { - Wisata Kuliner } \\
\text { - Wisata Outboun } \\
\text { - Wisata Kesenia } \\
\text { - Wisata Agro }\end{array}$ & & 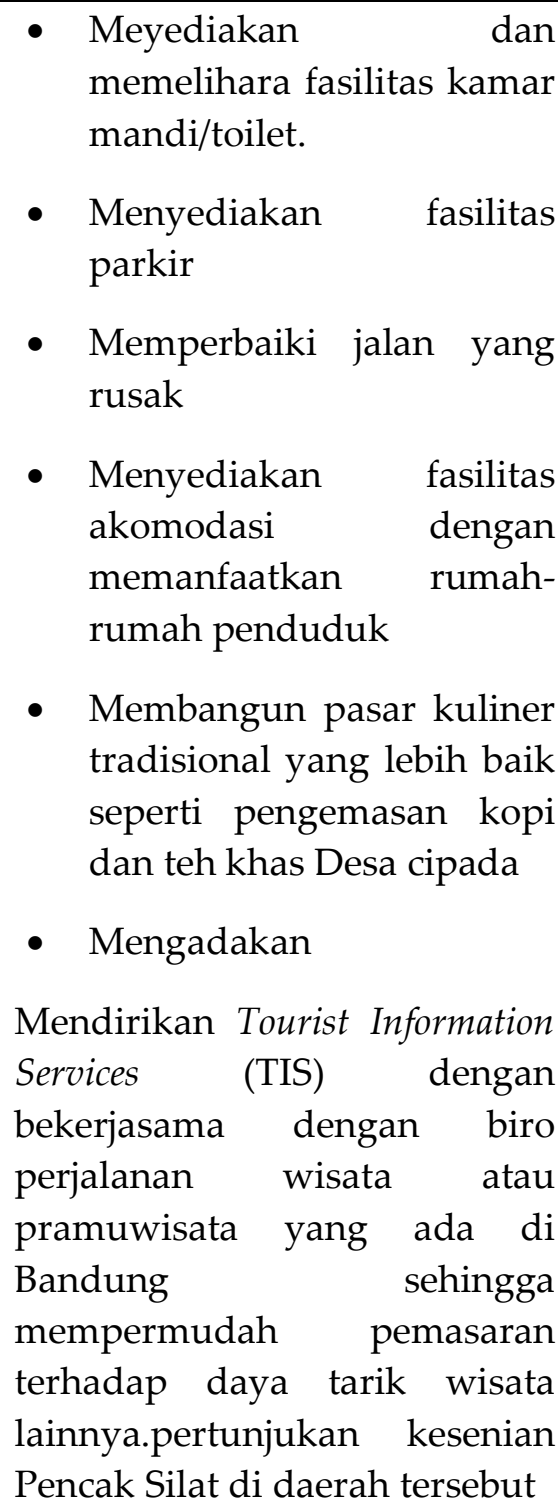 \\
\hline Ancaman & $\mathrm{S}+\mathrm{T}$ & $\mathrm{W}+\mathrm{T}$ \\
\hline $\begin{array}{l}\text { - Kondisi Lingkungan } \\
\text { yang berada di } \\
\text { kawasan Patahan } \\
\text { Lembang yang rawan } \\
\text { Gempa }\end{array}$ & $\begin{array}{l}\text { menjaga dan meningkatkan } \\
\text { keamanan situ lembang } \\
\text { Dano dan lingkungan Desa } \\
\text { Cipada }\end{array}$ & $\begin{array}{lr}\text { - } & \text { Membentuk } \\
\text { pengelola } & \text { lembariwisata } \\
\text { sehingga } & \text { dapat } \\
\text { mempermudah } & \text { dalam } \\
\text { melakukan perencanaan }\end{array}$ \\
\hline
\end{tabular}




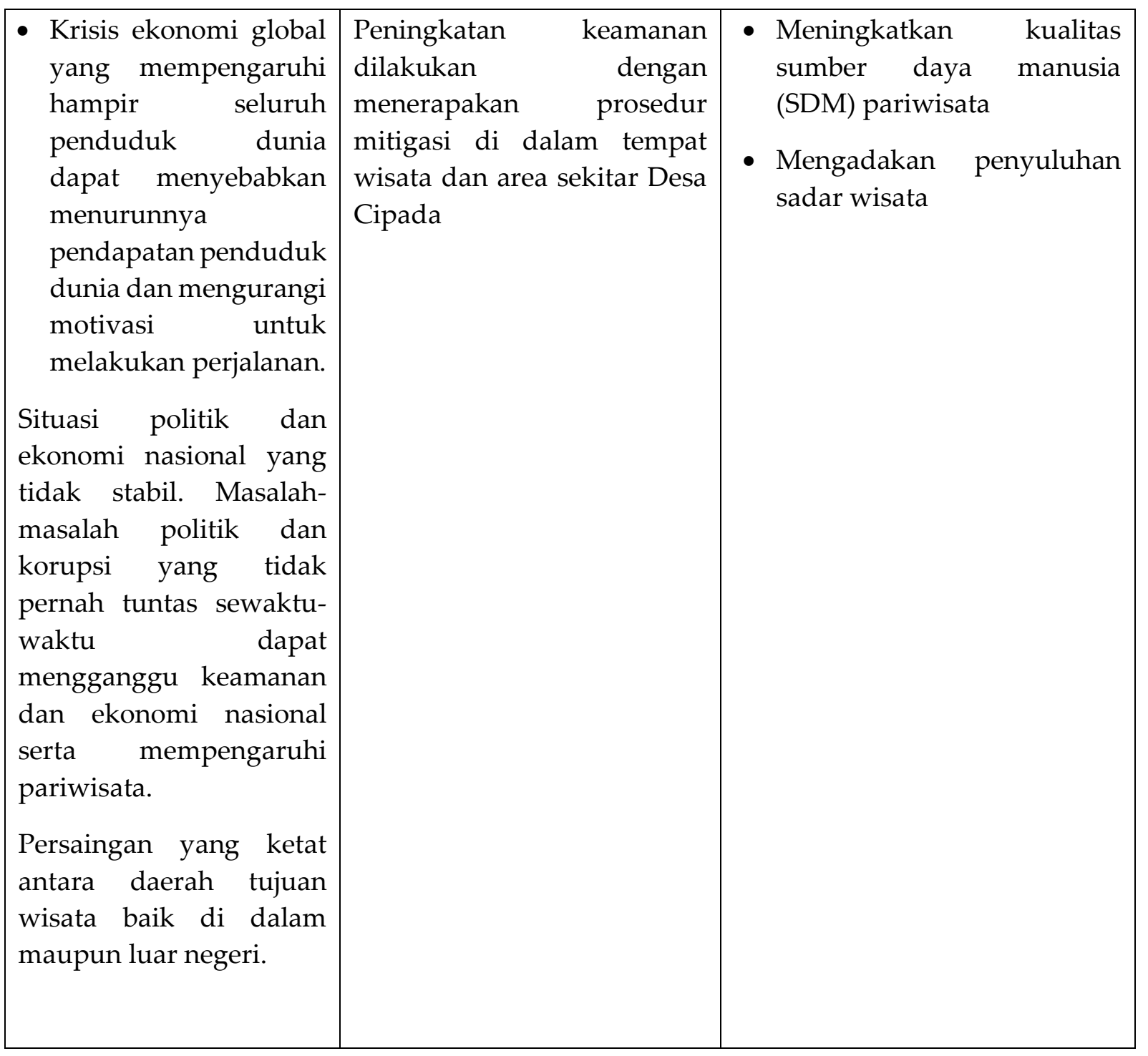

\section{Simpulan dan Saran}

Berdasarkan hasil penelitian dapat di simpulkan hal - hal sebagai berikut. Dalam penelitian ini beragam potensi pariwisata di Desa Cipada memiliki sumber daya alam yang berciri sektor pertanian dan agro Industri. Kondisi sumber daya alam memiliki potensi yang besar untuk dikembangkan. Strategi dalam mengembangkan Situ Lembang Dano adalah dengan cara meningkatkan kerja sama dengan pemerintah, mengembangkan potensi pariwisata di area Situ Lembang Dano Desa Cipada, Meningkatkan kualitas sumber daya manusia (SDM) pariwisata, 
pembangunan sarana dan prasarana, peningkatan infrastruktur serta peningkatan dan mengadakan penyuluhan sadar wisata.

Dalam upaya mengembangkan Situ Lembang Dano pentingnya kesadaran masyarakat sekitar untuk selalu menjaga lingkungan sekitar situ Lembang dano dan tidak merusak alam sekitar agar selalu terjaga keindahannya.

\section{Ucapan Terima Kasih}

Ucapan terima kasih kepada Bapak Kepala Desa Cipada yang telah membantu memberikan segala informasi yang penulis butuhkan.

\section{Daftar Pustaka}

Budayasa I K. (2016). Pengembangan wisata trekking di kawasan danau buyan, desa pancasari, kabupaten buleleng. JUMPA 2 [2] : 143 - 154

Demolingo R H. (2017). Strategi pengembangan destinasi wisata Desa bongo, kabupaten gorontalo. JUMPA 1 [2] : 67 - 82) P ISSN 2301-878X - E ISSN 24069116

Djuwendah E, Haspsari H, Enaldy E, Saidah Z. (2013). Strategi pengembangan daerah tertinggal di kabupaten garut. Jurnal Sosiohumaniora Volume 15 no. 2 Juli 2013: $211-221$

Manalu F C. (2016). Strategi pengembangan pariwisata berbasis masyarakat di pulau samalona, makassar. JUMPA 3 [1] : 175 - 189 ISSN 2406-9116

Nalayani N N. (2016). Evaluasi dan strategi pengembangan desa wisata di kabupaten badung, balI. JUMPA 2 [2] : 189 - 198 ISSN 2406-9116

Wulandari S N. (2016) Strategi Pengembangan daya tarik wisata budaya di desa sangsit jagaraga dan Sawan Kecamatan Sawan Kabupaten Buleleng Bali.Fakultas Ekonomi dan Bisnis Universitas Mataram. TESIS 


\section{Profil Penulis}

Tita Juwita, S.Pd. Lulusan Pendidikan Kesejahteraan Keluarga di Universitas Pendidikan Indonesia. Lahir di Bandung, 19 Januari 1990. Saat ini menjabat sebagai Kepala Program Perhotelan di SMK Mandala Putra 1, Kabupaten Bandung Barat, Indonesia. Saat ini bekerja sebagai guru Sekolah Menengah Kejuruan di Departemen Perhotelan di SMK Negeri 1 Cisarua, Kabupaten Bandung Barat, Indonesia. Saat ini Belajar di Program Magister Pariwisata Berkelanjutan di Universitas Padjadjaran. Kepala Organisasi Guru Perhotelan di Kabupaten Bandung Barat, Anggota Organisasi Guru Perhotelan di Jawa Barat. Asesor Kompetensi Penilaian Siswa Sekolah Menengah Kejuruan Front Office Department di Kabupaten Bandung Barat. Guru Jurusan Housekeeping di SMK Negeri 15 Bandung (2013). Training di Housekeeping Departement di Isola Resort Bandung (2014). Order Taker di Departemen Housekeeping di Grand Guci Hotel (2015). Resepsionis di Batoe Hotel Bandung (2015). Guru Reservasi dan Sumber Daya Manusia di SMK 45 Lembang (2015).

Prof. Dr. Reiza D. Dienaputra, M.Hum. adalah guru besar Fakultas Ilmu Budaya Universitas Padjadjaran dan guru besar pada Prodi Magister Pariwisata Berkelanjutan Sekolah Pascasarjana Universitas Padjadjaran. Saat ini ia menjabat sebagai Ketua Aliansi Strategis Universitas Padjadjaran - Jawa Barat (ASUP JABAR), suatu lembaga yang memfokuskan pada penguatan kapasitas sumber daya manusia di kota/kabupaten di Jawa Barat. Ia banyak menulis artikel di jurnal ilmiah dan media masa berkaitan dengan sejarah visual dan sejarah.

Dr. Awaludin Nugraha, M.Hum. adalah lektor kepala pada Prodi Magister Pariwisata Berkelanjutan Sekolah Pascasarjana Universitas Padjadjaran. Ia menyelesaikan pendidikan tingkat S1 di Jurusan Sejarah Indonesia Universitas Padjadjaran, S2 di Prodi Sejarah Universitas Gadjah Mada, dan S3 di Prodi Doktor 
Kajian Pariwisata Universitas Gadjah Mada. Ia melakukan penelitian dan menulis artikel pada jurnal ilmiah berkaitan dengan pariwisata berbasis budaya dan kearifan lokal serta sejarah pariwisata.

Dr. Evi Novianti. S.Sos., M.Si Dosen dan peneliti sejak 2003 di Program Studi Hubungan Masyarakat Fakultas Ilmu Komunikasi, Universitas Padjadjaran yang telah menyelesaikan studi Doktoralnya dan memiliki pengalaman spesialis di bidang Hubungan Masyarakat, Studi Komunikasi dengan fokus pada studi di Budaya dan Pariwisata. Kompetensi yang dikuasai yaitu Hubungan Masyarakat dan Komunikasi Antaretnis. Dalam karir akademiknya, ia menjabat sebagai Sekretaris Program Studi Magister Ilmu Komunikasi (S2) Unpad periode 2016-2018, dan saat ini terdaftar sebagai Ketua Program Studi Magister Pariwisata Berkelanjutan di Universitas Padjadjaran (2018-sekarang). Selain menjadi guru dalam kursus; Pengantar Hubungan Masyarakat, Teori Komunikasi, Audit Hubungan Masyarakat, Periklanan, Acara PR, Komunikasi Pariwisata. Aktif dalam berbagai studi, memberikan pelatihan, Pengabdian kepada Masyarakat, dan menjadi pembicara di forum seminar ilmiah nasional dan internasional. Penulis utama buku Teori Komunikasi, Pola Komunikasi Keluarga Antarbudaya, Komunikasi Bisnis Lintas Budaya dan rekan penulis Pengembangan Geodiversity \& Geotourism di Wilayah Kepulauan Seribu.

Dr. Drs. Rusdin Tahir., M.Si (www.rusdintahir.com), lahir di Bone, 14 Agustus 1966, saat ini bekerja sebagai Dosen dan Peneliti di Departemen Administrasi Bisnis, Universitas Padjadjaran, Bandung, Indonesia, sejak 1996 hingga sekarang. Lahir di Bone, 14 Agustus 1966, saat ini bekerja sebagai Dosen dan Peneliti di PT Jurusan Administrasi Bisnis, Universitas Padjadjaran, Bandung, Indonesia, sejak 1996 hingga sekarang. Mampu Subjek Organisasi dan Manajemen, Strategi Sumber Daya Manusia, Pengukuran Kinerja dan Strategi Kompensasi, Perilaku Organisasi, Perilaku 
Organisasi, Filsafat Ilmu Pengetahuan, dan Metodologi Penelitian dalam Program Studi Sekolah Pascasarjana Pariwisata Berkelanjutan Universitas Padjadjadjaran, Bandung, Indonesia, dan Master \& Program Studi Doktor Program Pascasarjana Ilmu Administrasi Bisnis di Universitas Padjadjadjaran, Bandung, Indonesia. Pakar di bidang perilaku organisasi dan strategi sumber daya manusia. Sarjana \& Pascasarjana: Administrasi Bisnis, Universitas Pendidikan Indonesia (1992); Gelar Master di Universitas Padjadjaran (2000); Gelar Doktor di Universitas Padjadjaran (2013). Bidang minat: Ilmu Manajemen dan Ilmu Administrasi Bisnis. Karya Ilmiah: Pengaruh Penerapan Lingkaran Kontrol Kualitas terhadap Kinerja Pekerjaan Karyawan (1991); Dimensi Strategi Sumber Daya Manusia \& Strategi Alih Teknologi Sebagai Penentu Balanced Scorecard berbasis Kinerja Perusahaan (1999); Kualitas kehidupan kerja, Kewarganegaraan Organisasi, Keterlibatan karyawan, total scorecard (2012); Kompetensi Karyawan dan Strategi Kompensasi sebagai Upaya Strategis Perusahaan untuk Meningkatkan Kinerja Karyawan (2019). 